\title{
Four year survival in untreated AIDS related-Kaposi sarcoma (AIDS-KS) in Jos, Nigeria
}

\author{
P Agaba*, E Anya, Z Hassan, L Apena, O Agbaji, M Mua'Zu, B Badung and \\ J Idoko
}

Address: AIDS Prevention Initiative Nigeria Plus (Harvard PEPFAR) Centre, Jos University Teaching Hospital, Nigeria

* Corresponding author

\author{
from I I th International Conference on Malignancies in AIDS and Other Acquired Immunodeficiencies (ICMAOI): Basic, Epidemiologic, and Clinical \\ Research \\ Bethesda, MD, USA. 6-7 October 2008 \\ Published: 17 June 2009 \\ Infectious Agents and Cancer 2009, 4(Suppl 2):P3 doi:I0.I 186/I750-9378-4-S2-P3
}

This abstract is available from: http://www.infectagentscancer.com/content/4/S2/P3

(c) 2009 Agaba et al; licensee BioMed Central Ltd.

\section{Background}

AIDS-KS remains a significant cause of morbidity and mortality especially in sub-Saharan Africa in the face of ART scale-up. We compare survival over a four-year period between HIV-infected men and women with untreated AIDS-KS receiving care in Jos, Nigeria.

\section{Patients and methods}

The Jos University Teaching Hospital HIV cohort has more than 10,500 adult patients enrolled for care. We prospectively collect routine data on individuals, and during the study 175 patients presenting with AIDS-KS were followed up. We compared survival, clinical, immunologic and virologic characteristics between male and female patients receiving HAART (two NRTIs and one NNRTI). Comparison of variables between groups was by $\chi^{2}$ test for nominal variables. Survival was calculated from the day of enrollment until death or the date of last follow-up using Kaplan-Meier method (Figure 1).

\section{Results}

One hundred and three (58.8\%) were females while 72 (41.2\%) were males, giving a male: female ratio of 1:1.6. The mean age was $35 \pm 7$ and $40 \pm 7$ for females and males respectively $(\mathrm{p}<0.001)$. Median CD4 count was 105 and 114 cells $/ \mathrm{mm}^{3}(\mathrm{p}, 0.76)$ while HIV RNA was 43,113 and 80,310 ( $\mathrm{p}, 0.01$ ) median copies $/ \mathrm{ml}$ for females and males respectively at baseline. Mean duration of observation was similar for both sexes $(2.3 \pm 0.9$ years $)$ with $18.4 \%$ of females and $13.9 \%$ of males having history of use of HAART. Seventy-five percent $(75 \%)$ of the females and 80 percent of the males had disseminated cutaneous disease and more than 40 percent of the male had nodular lesions compared with 25.5 percent of the females. The probability of survival was similar for both sexes.

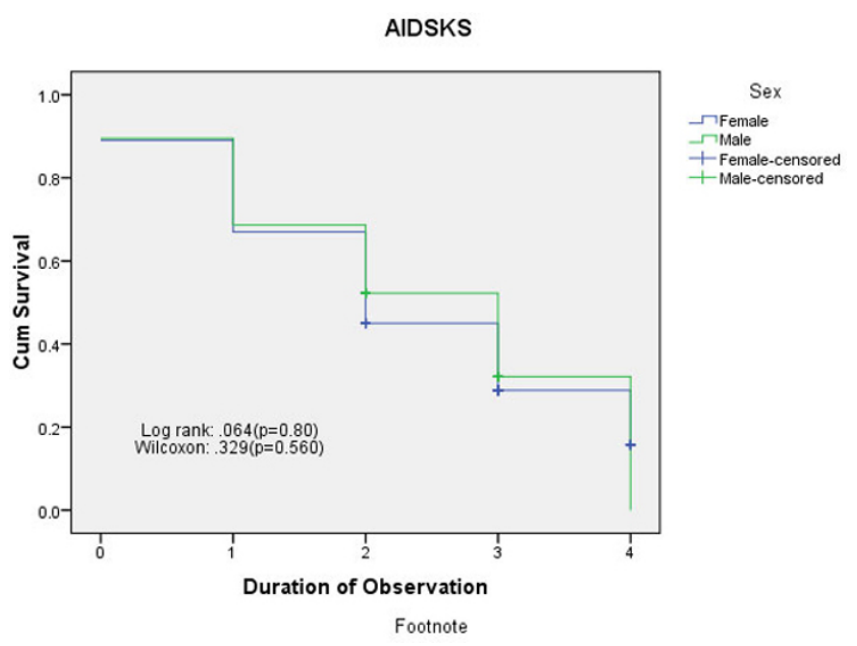

Figure I

Kaplan-Meier plot for $\mathrm{HIV}^{+}$patients with untreated AIDS-KS in Jos, Nigeria stratified by sex. 


\section{Conclusion}

Despite the availability of HAART, AIDS-KS continues to significantly affect morbidity and mortality in HIVinfected patients in our setting. Provision of specific treatment for AKS may improve overall outcome.

Publish with Bio Med Central and every scientist can read your work free of charge

"BioMed Central will be the most significant development for disseminating the results of biomedical research in our lifetime. " Sir Paul Nurse, Cancer Research UK

Your research papers will be:

- available free of charge to the entire biomedical community

- peer reviewed and published immediately upon acceptance

- cited in PubMed and archived on PubMed Central

- yours - you keep the copyright 